\title{
TEXTURAL - HEAVY MINERALS CHARACTERIZATION OF FORESHORE - BACKSHORE SEDIMENTS, MARSA ALAM- WADI AL JIMAL, RED SEA COASTAL ZONE, EGYPT
}

\author{
Elshahat, O. R. \\ Geology Department, Faculty of Science, Al-Azhar University, Cairo, Egypt, 11884 \\ osamaramzy80@azhar.edu.eg
}

\begin{abstract}
Grain size processing and heavy minerals separation carried out on 22 and 25 representative samples of foreshore and backshore sediments respectively collected from the Coastal zone between Marsa Alam and Wadi El-Jimal. The intertidal sediments are chiefly coarse-grained (15 samples), moderately (4 samples) to poorly sorted (15 samples), symmetrical (6 samples) to coarse-skewed ( 9 samples) and very leptokurtic to very platykurtic. The beach sediments are medium (11 samples) to coarse-grained ( 8 samples), moderately well to poorly sorted, symmetrical $(9$ samples) to coarse-skewed (11 samples) and very leptokurtic to very platykurtic.

The average total heavy mineral contents in the $(0.250-0.125 \mathrm{~mm})$ fine sand fraction of both sediments are $28.10 \%$ and $16.90 \%$ respectively, and in the $(0.125-0.0 .63 \mathrm{~mm})$ very fine sand fraction are $52.95 \%$ and $25.64 \%$ respectively. The heavy minerals identified are predominantly iron-bearing minerals (magnetite and goethite), titanium-bearing minerals (sphene and rutile), pyroxene, barite, biotite, plagioclase, cetrine, sillimanite, garnet, apatite, fluorite, tourmaline, topaz and olivine.

The gabbroic, dolerite, basaltic rocks, alkali feldspar granites, granodiorites, tonalite, quartz diorite, monzogranite, syenogranites and metamorphic rock assemblages encountered in Wadi Alam, Wadi Samadai, Wadi Ghadir and Wadi El- Jimal are the main source for the detected heavy minerals.
\end{abstract}

Keywords: Red sea, Foreshore and backshore sediments, Grain size, Depositional environment, Heavy minerals.

\section{INTRODUCTION}

The study area lies between latitudes $25^{\circ} 03^{\prime} 50^{\prime \prime}$ and $24^{\circ} 39^{\prime} 52^{\prime \prime} \mathrm{N}$ and longitudes $34^{\circ} 54^{\prime} 08^{\prime \prime}$ and $35^{\circ}$ 3' 03" E covering about $45 \mathrm{Km}$. from Mars Alam City to entrance of Wadi Al Jimal. The study area can be accessed by a paved road runs north-south along the coastal plain of the Red Sea. The climate of the region is extremely arid, with rainfall averaging less than $1 \mathrm{~cm}$. per year, and daytime temperatures averaging $20^{\circ}$ to $30^{\circ}$ Celsius (Greene, 1984). The studied area is dissected by several main wadies chiefly, W. Samadai, W. Umbauut, W. Esbkhat, W. Ghadir, W. Sharm al Fuqari and W. Al Jimal (Fig. 1).

The Eastern Desert of Egypt includes the area between the Nile River and the Gulf of Suez/Red Sea. Its most prominent feature is a north-northwest trending range of mountains that parallels to the Red Sea coast. The Panafrican Orogeny within the Eastern Desert of Egypt is characterized by a nappe assembly that includes ophiolite nappes and related magmatic and sedimentary assemblages (Panafrican nappes: e.g., Ries et al., 1983, Kröner et al., 1994, Greiling et al., 1994, and Fritz et al., 1996), which are thrusted over polymetamorphosed and polydeformed basement units (Neumayr et al., 1998).

The concentration of barium in beach sediments between Marsa Alam and Shuqeir (El-Mamoney and Rifaat, 2001), the environmental characterization and radio-ecological impacts of non-nuclear industries (El Mamoney and Khater, 2004), the geochemistry and sedimentology of core sediments and the influence of human activities (Ahmed, 2005), the provenance of recent sediments along the Red Sea coast 
Textural - heavy minerals characterization of foreshore - backshore

(Ramadan and Zaid 2016) and the provenance of recent sediments and the radiological aspects of water, soil and shore sediments resources (Arafat et al., 2017) were studied.

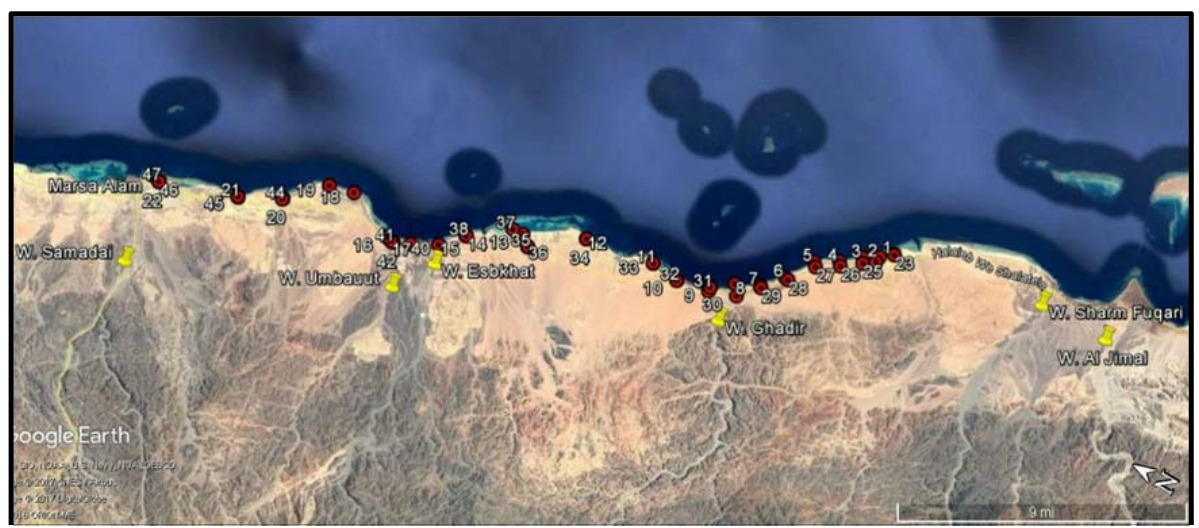

Fig. 1: Landsat image showing the sites of the studied samples and the main wadies in the study area.

Grain size parameters of the study beach sediments between Marsa Alam and Wadi El-Jimal is presented here as an approach to evaluate the textural parameters and the heavy mineral concentrations to understand the mineral distribution in relation to source rocks.

The basement rocks cropping out at the upper reaches of the study area (Fig. 2), are dominated by a sequence of ophiolites, metavolcanics and meta-volcano-sedimentary rocks (Valentine 1985). The Cenozoic sequence exposed in the study area, are of Miocene to Pleistocene age, represented from older by Ranga, Um Mahara, Abu Dabbab, Um Gheig, Samh, Gabir, Shagra and Samadai formations (Said 1990).

Fig. 2: Geologic map of north Marsa Alam area, (after Zaid 2015).

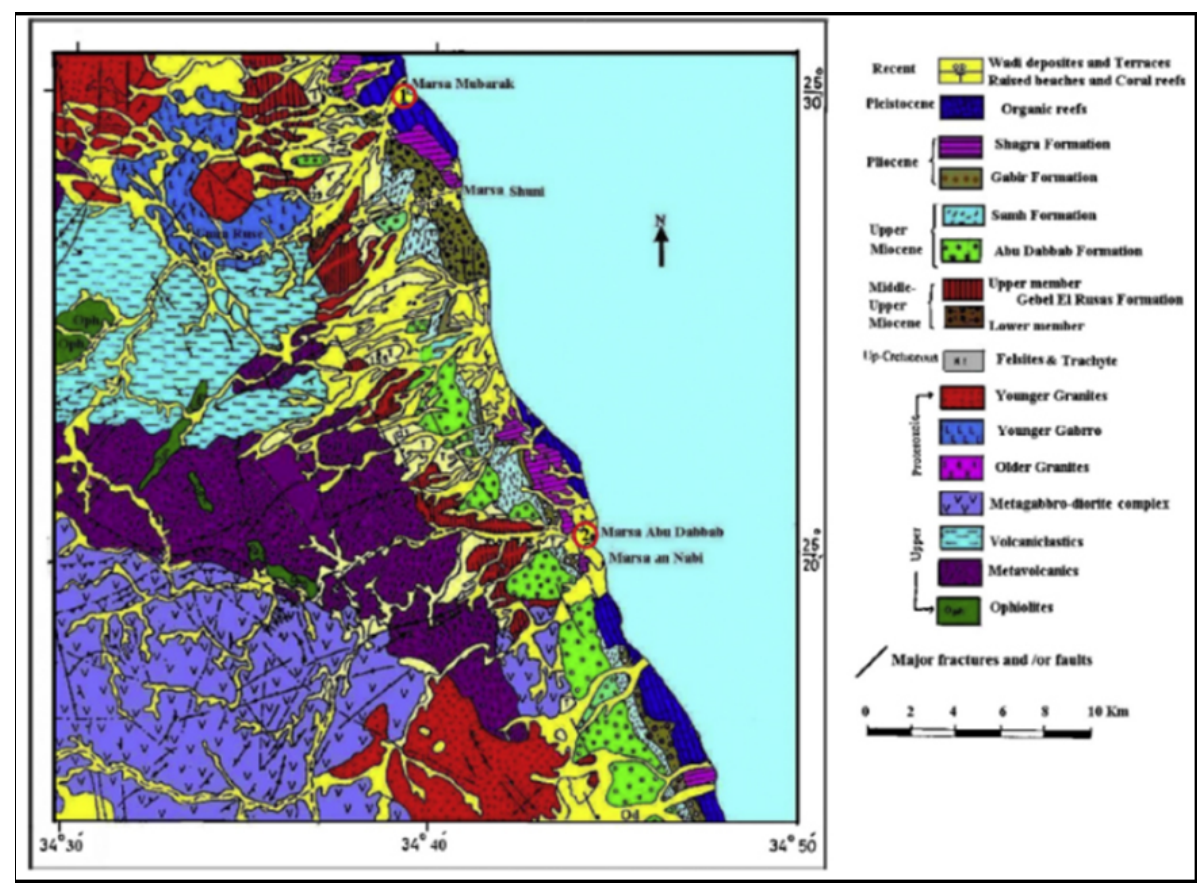

\section{METHODOLOGIES}

A total of 22 foreshore and 25 backshore samples were collected at $\sim 40 \mathrm{~cm}$ depth from the studied coastal zone (Fig. 1), each of $\sim 2 \mathrm{~kg}$. Geographical position was defined using GPS.

Sieving technique is applied to separate the various grain size-classes, following Ingram (1971). The computational method of Folk and Ward (1957) was used to calculate grain size statistical parameters. Particle size data obtained was processed using the GRADISTAT grain size software (Blott and Pye 2001). 
Elshahat, O. R.

The fine and very fine sand fractions $(0.125-0.073 \mathrm{~mm})$ of all samples were further subjected to heavy mineral separation to separate the heavy and light minerals using bromoform $\left(\mathrm{Sp} . \mathrm{Gr} .=2.89 \mathrm{~g} / \mathrm{cm}^{3}\right)$. The relative abundances of the heavy mineral species of both fractions were determined by point counting of 500 grains using the standard petrographic techniques, each mineral grains of each grain size were obtained and converted to modal \%. Moreover, EDX chemical analyses of the identified heavy minerals were carried out using a Phillips XL-30 Environmental Scanning Electron Microscope (ESEM) in the laboratories of Nuclear Materials Authority (NMA).

\section{RESULTS AND INTERPRETATION}

\section{Textural studies}

A representative sub-sample weighting about $500 \mathrm{gm}$ was taken from each prepared sample and subject to grain size analysis. The graphic mean diameter $\left(\mathrm{M}_{\mathrm{z}}\right)$, standard deviation $\left(\sigma_{\mathrm{I}}\right)$, inclusive graphic skewness $\left(\mathrm{Sk}_{\mathrm{I}}\right)$ and graphic kurtosis $\left(\mathrm{K}_{\mathrm{G}}\right)$ were calculated for the studied sediments (tables 1, 2 and 3 ) using the equations given by Folk and Ward (1957).

The results show that the intertidal and beach sediments are chiefly sands and/or gravels with slight amount of silt and clay (tables $1 \& 2$ ). From figure (3a), most intertidal samples plot in gravely sand class, few are slightly gravely sand. Those of beach signify sand and gravely sand - slightly gravely sand class (Fig. 3b). Gravel and coarser sand fractions are mostly composed of skeletal and shell fragments. Most of the studied sediments are unimodal grain -size distribution patterns, recommending a single stream organization, while two stream regimes are suggested for the bimodal bar graph sediments. The cumulative curves show almost similar trends with a predominance of sand size.

\begin{tabular}{|c|c|c|c|c|c|c|c|c|c|c|c|c|c|}
\hline S. & $\begin{array}{l}\text { Mean } \\
\text { Size }\end{array}$ & $\begin{array}{l}\text { Standard } \\
\text { Deviatio }\end{array}$ & Skweness & Kurtosi & \multicolumn{4}{|c|}{ Remarks } & \multirow{2}{*}{$\begin{array}{c}\begin{array}{c}\text { Gravel } \\
\text { \% }\end{array} \\
15.2 \\
\end{array}$} & \multirow{2}{*}{$\begin{array}{c}\begin{array}{c}\text { Sand } \\
\%\end{array} \\
84.8 \\
\end{array}$} & \multirow{2}{*}{$\begin{array}{c}\begin{array}{c}\text { Mud } \\
\%\end{array} \\
0 \\
\end{array}$} & \multirow{2}{*}{$\begin{array}{c}\begin{array}{c}\text { Sample } \\
\text { Type }\end{array} \\
\text { Un, PSo }\end{array}$} & \multirow{2}{*}{$\begin{array}{c}\begin{array}{c}\text { Texture } \\
\text { group }\end{array} \\
\text { GS } \\
\end{array}$} \\
\hline 1 & 0.763 & 1.514 & -0.243 & 0.896 & $\mathrm{CS}$ & PSo & CSk & Pkg & & & & & \\
\hline 2 & 0.282 & 1.224 & -0.032 & 1.115 & CS & PSo & SSk & Lkg & 15.5 & 85.5 & 0 & Un, PSo & GS \\
\hline 3 & 0.291 & 1.337 & -0.112 & 1.045 & $\mathrm{CS}$ & PSo & CSk & Mkg & 17.3 & 82.6 & 0.1 & Un, PSo & GS \\
\hline 4 & 0.371 & 1.416 & -0.345 & 0.771 & $\mathrm{CS}$ & PSo & VCSk & Pkg & 21.6 & 78.3 & 0 & Bi, PSo & GS \\
\hline 5 & -0.505 & 0.963 & -0.043 & 0.536 & VCS & MSo & SSk & VPKg & 30.8 & 69.2 & 0 & Un, MSo & SG \\
\hline 6 & 0.218 & 0.990 & 0.211 & 0.329 & $\mathrm{CS}$ & MSo & FSk & VPKg & 37.3 & 62.7 & 0 & Un, MSo & SG \\
\hline 7 & -0.710 & 0.375 & 2.139 & 0.424 & VCS & WSo & VFSk & VPKg & 55.7 & 44.3 & 0.1 & Un, WSo & SG \\
\hline 8 & -0.135 & 0.885 & 0.411 & 0.302 & VCS & MSo & VFSk & VPKg & 36.7 & 63.3 & 0 & Un, MSo & SG \\
\hline 9 & 0.655 & 1.323 & 0.036 & 1.125 & $\mathrm{CS}$ & PSo & SSk & $\mathrm{Lkg}$ & 9.4 & 89.8 & 0.7 & Un, PSo & GS \\
\hline 10 & 0.345 & 1.343 & -0.332 & 0.827 & $\mathrm{CS}$ & PSo & VCSk & Pkg & 20.1 & 79.2 & 0.7 & Un, PSo & GS \\
\hline 11 & 0.280 & 1.147 & 0.004 & 0.930 & $\mathrm{CS}$ & PSo & SSk & Mkg & 13.2 & 86.8 & 0.1 & Un, PSo & GS \\
\hline 12 & 0.996 & 1.446 & -0.253 & 0.954 & $\mathrm{CS}$ & PSo & CSk & $\mathrm{Mkg}$ & 11.50 & 88.20 & 0.30 & Un, PSo & GS \\
\hline 13 & 2.171 & 1.193 & -0.330 & 2.879 & FS & PSo & VCSk & VLKg & 5.30 & 94.40 & 0.30 & Un, PSo & GS \\
\hline 14 & 0.717 & 0.940 & 0.012 & 1.020 & $\mathrm{CS}$ & MSo & SSk & Mkg & 4.40 & 95.60 & 0.00 & Un, MSo & SGS \\
\hline 15 & 1.167 & 1.234 & -0.187 & 1.079 & MS & PSo & CSk & Mkg & 7.30 & 92.60 & 0.10 & Un, PSo & GS \\
\hline 16 & 0.032 & 1.044 & 0.162 & 1.879 & $\mathrm{CS}$ & PSo & FSk & VLKg & 7.50 & 91.30 & 1.20 & Bi, PSo & GS \\
\hline 17 & 0.523 & 1.327 & -0.134 & 1.117 & $\mathrm{CS}$ & PSo & CSk & $\mathrm{Lkg}$ & 13.60 & 86.40 & 0.00 & Un, PSo & GS \\
\hline 18 & 0.368 & 1.250 & -0.080 & 0.750 & $\mathrm{CS}$ & PSo & SSk & Pkg & 18.20 & 81.70 & 0.00 & Un, PSo & GS \\
\hline 19 & 1.066 & 0.636 & -0.182 & 1.317 & MS & MWSo & CSk & Lkg & 2.60 & 97.30 & 0.00 & Un, MWSo & SGS \\
\hline 20 & 0.139 & 0.495 & -0.213 & 1.112 & $\mathrm{CS}$ & WSo & CSk & Lkg & 4.60 & 95.40 & 0.00 & Un, WSo & SGS \\
\hline 21 & 0.906 & 1.007 & -0.163 & 1.154 & $\mathrm{CS}$ & PSo & CSk & Lkg & 5.8 & 94.1 & 0.1 & Un, PSo & GS \\
\hline 22 & 1.544 & 1.380 & -0.209 & 1.466 & MS & PSo & CSk & Lkg & 8.2 & 91.6 & 0.2 & Un, PSo & GS \\
\hline Min. & -0.13 & 0.37 & -0.043 & 0.302 & & & & & 2.6 & 44.3 & $\mathbf{0}$ & & \\
\hline Max. & 2.17 & 1.514 & 2.13 & 2.87 & & & & & 55.7 & 97.3 & 1.2 & & \\
\hline Avg. & 0.522 & 1.11 & 0.005 & 1.04 & & & & & 16.44 & 83.41 & 0.17 & & \\
\hline
\end{tabular}

Table 1: Intertidal textural composition and descriptive statistical analysis for the grain size parameters.

Table (3) shows that the majority of the mean size values (Fig. 4a) fall into the very coarse to medium sand classes for the foreshore sediments and coarse to medium sand classes for the backshore sediments (Fig. 4b). The coarse- medium sand pointing to deposition in high to moderate and occasionally environment (Singarasubramanian et al., 2006, Abdulkareem et al, 2011, Avramidis et al., 2012, Rajganapathi et al., 2013, Watson et al., 2013 and Amireh 2014). The fine to very coarse-graind grain size ranges of both sediments, indicates agitated rise and fall transporting agent (Fig. 5). 
Textural - heavy minerals characterization of foreshore - backshore
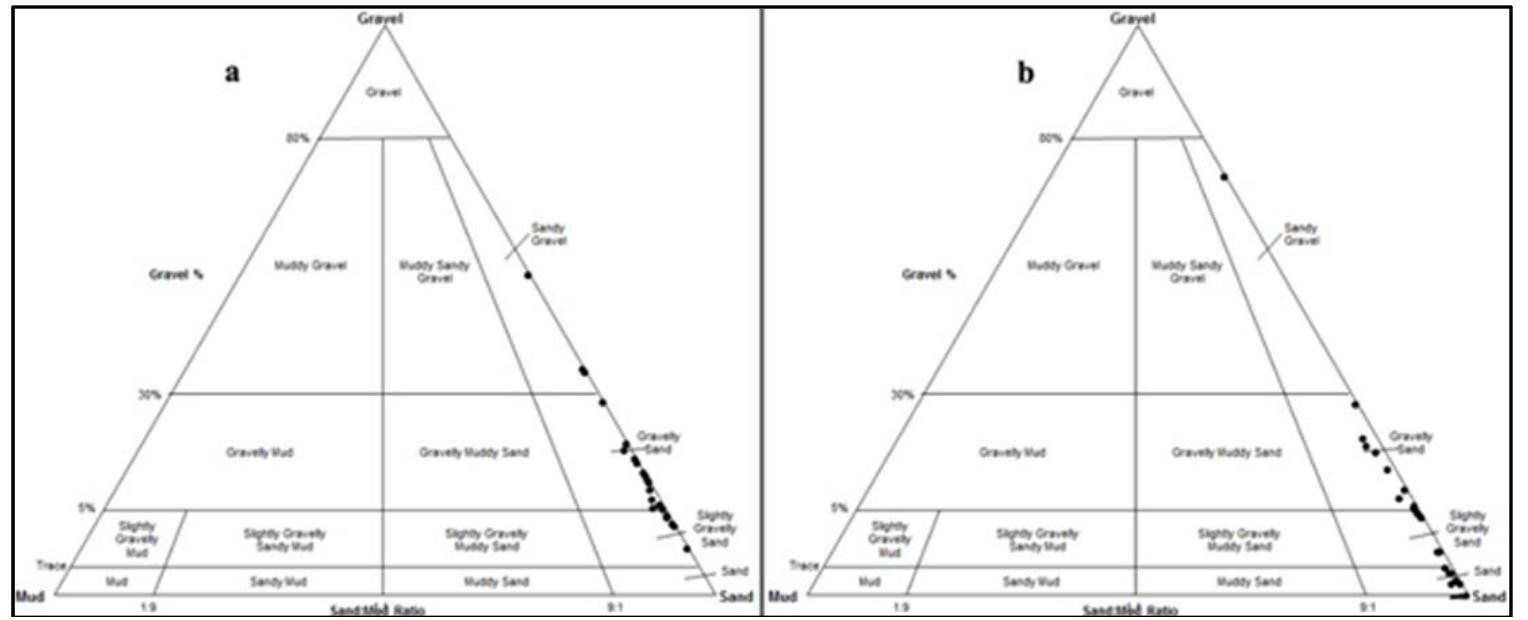

Fig. 3: Plotting of the studied sediments on the ternary diagram of Folk, 1954, of the studied intertidal (a) and beach (b) samples.

Table 2: Beach textural composition and descriptive statistical analysis for the grain size parameters.

\begin{tabular}{|c|c|c|c|c|c|c|c|c|c|c|c|c|c|}
\hline $\begin{array}{l}\text { S. } \\
\text { No. }\end{array}$ & $\begin{array}{l}\text { Mean } \\
\text { Size } \\
(\mathrm{MZ})\end{array}$ & $\begin{array}{l}\text { Standard } \\
\text { Deviation } \\
\text { (бI) }\end{array}$ & $\begin{array}{l}\text { Skweness } \\
\text { (SK) }\end{array}$ & $\begin{array}{l}\text { Kurtosis } \\
\text { (KG) }\end{array}$ & \multicolumn{4}{|c|}{ Remarks } & $\begin{array}{c}\text { Grave } \\
1 \%\end{array}$ & $\begin{array}{c}\text { Sand } \\
\%\end{array}$ & $\begin{array}{l}\text { Mud } \\
\%\end{array}$ & Sample Type & $\begin{array}{l}\text { Texture } \\
\text { group }\end{array}$ \\
\hline 23 & 2.005 & 0.571 & -0.255 & 1.060 & FS & MWSo & CSk & Mkg & 0.1 & 99.7 & 0.1 & Un, MWSo & SGS \\
\hline 24 & 1.485 & 1.210 & -0.346 & 1.556 & MS & PSo & VCSk & VLKg & 7.2 & 92.5 & 0.3 & Un, PSo & GS \\
\hline 25 & 0.896 & 1.431 & -0.030 & 0.921 & $\mathrm{CS}$ & PSo & SSk & Mkg & 9.6 & 89.2 & 1.3 & Un, PSo & GS \\
\hline 26 & 0.517 & 1.552 & -0.100 & 0.678 & $\mathrm{CS}$ & PSo & CSk & PKg & 21 & 77.4 & 1.6 & Un, PSo & GS \\
\hline 27 & 1.544 & 0.755 & 0.032 & 1.052 & MS & MSo & SSk & Mkg & 2.4 & 97.2 & 0.4 & Un, MSo & SGS \\
\hline 28 & 1.224 & 0.659 & -0.052 & 1.555 & MS & MWSo & SSk & VLKg & 2.4 & 97.3 & 0.2 & Un, MWSo & SGS \\
\hline 29 & -0.782 & 0.410 & 3.998 & -7.176 & VCS & WSo & VFSk & VPKg & 74.9 & 25 & 0 & Bi, WSo & SG \\
\hline 30 & 1.308 & 0.575 & 0.069 & 1.340 & MS & MWSo & SSk & LKg & 0.4 & 99.3 & 0.3 & Un, MWSo & SGS \\
\hline 31 & 1.335 & 0.649 & 0.077 & 1.393 & MS & MWSo & SSk & $\mathrm{LKg}$ & 1.1 & 98.2 & 0.6 & Un, MWSo & SGS \\
\hline 32 & 1.169 & 1.040 & -0.183 & 1.518 & MS & PSo & CSk & VLKg & 5.6 & 94.3 & 0.1 & Un, PSo & GS \\
\hline 33 & 1.121 & 1.183 & -0.250 & 1.657 & MS & PSo & CSk & VLKg & 7.9 & 92 & 0.1 & Un, PSo & GS \\
\hline 34 & 0.562 & 1.165 & -0.240 & 1.241 & $\mathrm{CS}$ & PSo & CSk & LKg & 11.40 & 88.40 & 0.20 & Un, PSo & GS \\
\hline 35 & 1.213 & 1.167 & -0.217 & 1.372 & MS & PSo & CSk & $\mathrm{LKg}$ & 6.30 & 93.40 & 0.30 & Un, PSo & GS \\
\hline 36 & 2.216 & 0.478 & -0.118 & 1.262 & FS & WSo & CSk & $\mathrm{LKg}$ & 0.70 & 99.00 & 0.30 & Un, WSo & SGS \\
\hline 37 & 2.25 & 0.71 & 0.02 & 1.341 & FS & MSo & SSk & $\mathrm{LKg}$ & 0.10 & 98.40 & 1.50 & Un, MSo & SGS \\
\hline 38 & 0.318 & 1.36 & -0.172 & 0.77 & CS & PSo & $\mathrm{CSk}$ & PKg & 19.80 & 79.30 & 0.90 & Un, PSo & GS \\
\hline 39 & 2.148 & 0.624 & -0.061 & 1.365 & FS & MWSo & SSk & LKg & 0.80 & 99.20 & 0.00 & Un, MWSo & SGS \\
\hline 40 & 2.308 & 0.65 & 0.051 & 1.354 & FS & MWSo & SSk & LKg & 0.10 & 99.30 & 0.60 & Un, MWSo & SGS \\
\hline 41 & 1.813 & 0.988 & -0.495 & 1.483 & MS & MSo & VCSk & $\mathrm{LKg}$ & 5.20 & 94.80 & 0.00 & Un, MSo & GS \\
\hline 42 & 0.052 & 1.635 & 0.523 & 0.51 & $\mathrm{CS}$ & PSo & VFSk & VPKg & 30.30 & 69.60 & 0.10 & Bi, PSo & SG \\
\hline 43 & 0.985 & 1.161 & -0.278 & 1.431 & $\mathrm{CS}$ & PSo & CSk & VPKg & 15.8 & 83.4 & 0.7 & Un, PSo & GS \\
\hline 44 & 0.954 & 0.604 & -0.219 & 0.567 & $\mathrm{CS}$ & MWSo & CSk & $\mathrm{LKg}$ & 0.4 & 99.6 & 0 & Un, MWSo & SGS \\
\hline 45 & 1.781 & 0.674 & -0.017 & 0.76 & MS & MWSo & SSk & $\mathrm{PKg}$ & 0.4 & 98.8 & 0.9 & Un, MWSo & SGS \\
\hline 46 & 1.996 & 0.68 & -0.125 & 1.109 & MS & MWSo & CSk & Mkg & 0.7 & 98.9 & 0.4 & Un, MWSo & SGS \\
\hline 47 & 0.813 & 1.805 & -0.461 & 0.566 & $\mathrm{CS}$ & PSo & VCSk & VPKg & 22.9 & 75.7 & 1.4 & Un, PSo & GS \\
\hline Min. & $\begin{array}{l}-0.78 \\
\end{array}$ & 0.4 & -0.03 & -7.17 & & & & & 0.1 & 25 & $\mathbf{0}$ & & \\
\hline Max. & 2.3 & 1.8 & 3.99 & 1.55 & & & & & 74.9 & 99.7 & 1.4 & & \\
\hline Avg. & 1.24 & 0.94 & 0.048 & 0.82 & & & & & 9.69 & 89.59 & 0.49 & & \\
\hline
\end{tabular}

The standard deviation of most of the studied foreshore sediments indicate poorly sorted (Fig. 4a), whereas those of the backshore sediments signify poorly sorted and occasionally moderately well sorted (Fig. 4b). The fine sediments are better sorted than the coarse and medium sediments (Tables $1 \& 2$ ), (Inman and Chamberlain 1955). The observed sorting variation (Fig. 6) attributes to the difference in water turbulence and variability in the velocity of depositing current and continuous adding of finer/coarser materials in varying proportions (Venkatraman et al., 2011).

Corroboration with Friedman and Sanders (1978) observation that the presence of skeletal remains adversely affects the sorting of sediments, $68 \%$ of the intertidal sediments are poorly sorted while this ration decreasing to $44 \%$ in the beach sediments (Table 3). For the foreshore sediments, the studied skewness varied between very fine to very coarse skewed, the backshore skewness values vary from fine skewed to very coarse skewed (Figs. $4 \mathrm{a} \& \mathrm{~b}$ and 7 ). 
Elshahat, O. R.

The foreshore sediments are chiefly leptokurtic to mesokurtic and very platykurtic to platykurtic sediments (Table 3). The beach sediments are chiefly leptokurtic to very leptokurtic sediments and occasionally platykurtic (Table 3). The data imply that the both sediments have the center portions better sorted than the tails part. The wide range value of the kurtosis Figs. $4 \mathrm{a} \& \mathrm{~b}$ and 8 ), suggests that part of the sediments achieved its sorting elsewhere in high-energy environment (Friedman 1962).

Table 3: Calculated percentages of the grain size parameters of intertidal and beach sediments.

\begin{tabular}{|c|c|c|c|c|c|c|c|c|c|c|c|c|}
\hline \multirow{2}{*}{$\begin{array}{c}\text { Type of } \\
\text { sediment }\end{array}$} & \multicolumn{3}{|c|}{ Mean Size (Mz) } & \multicolumn{3}{|c|}{ Standard Deviation $(\sigma \mathrm{I})$} & \multicolumn{3}{|c|}{ Skewness (Sk) } & \multicolumn{3}{|c|}{ Kurtosis $(\mathrm{Kg})$} \\
\hline & Class & $\begin{array}{c}\text { No. of } \\
\text { Samples }\end{array}$ & $\%$ & Class & $\begin{array}{c}\text { No. of } \\
\text { Samples }\end{array}$ & $\%$ & Class & $\begin{array}{c}\text { No. of } \\
\text { Samples }\end{array}$ & $\%$ & Class & $\begin{array}{c}\text { No. of } \\
\text { Samples }\end{array}$ & $\%$ \\
\hline \multirow{5}{*}{ Intertidal } & VCS & 3 & 13.63 & PSo & 15 & 68.18 & VFSk & 2 & 9.09 & VPKg & 4 & 18.18 \\
\hline & $\mathrm{CS}$ & 15 & 68.18 & MSo & 4 & 18.18 & FSk & 2 & 9.09 & $\mathrm{PKg}$ & 4 & 18.18 \\
\hline & MS & 3 & 13.63 & MWSo & 1 & 5.54 & SSk & 6 & 27.27 & $\mathrm{M}$ & 5 & 22.72 \\
\hline & FS & 1 & 4.54 & WSo & 2 & 9.09 & CSk & 9 & 40.90 & LKg & 7 & 31.81 \\
\hline & & & & & & & VCSk & 3 & 13.63 & VLKg & 2 & 9.09 \\
\hline \multirow{5}{*}{ Beach } & VCS & 1 & 4 & PSo & 11 & 44 & FSk & 2 & 8 & VPKg & 4 & 16 \\
\hline & $\mathrm{CS}$ & 8 & 32 & MSo & 3 & 12 & SSk & 9 & 36 & $\mathrm{PKg}$ & 3 & 12 \\
\hline & MS & 11 & 44 & MWSo & 9 & 36 & CSk & 11 & 44 & $\mathrm{M}$ & 4 & 16 \\
\hline & FS & 5 & 20 & WSo & 2 & 8 & VCSk & 3 & 12 & LKg & 10 & 40 \\
\hline & & & & & & & & & & VLKg & 4 & 16 \\
\hline
\end{tabular}
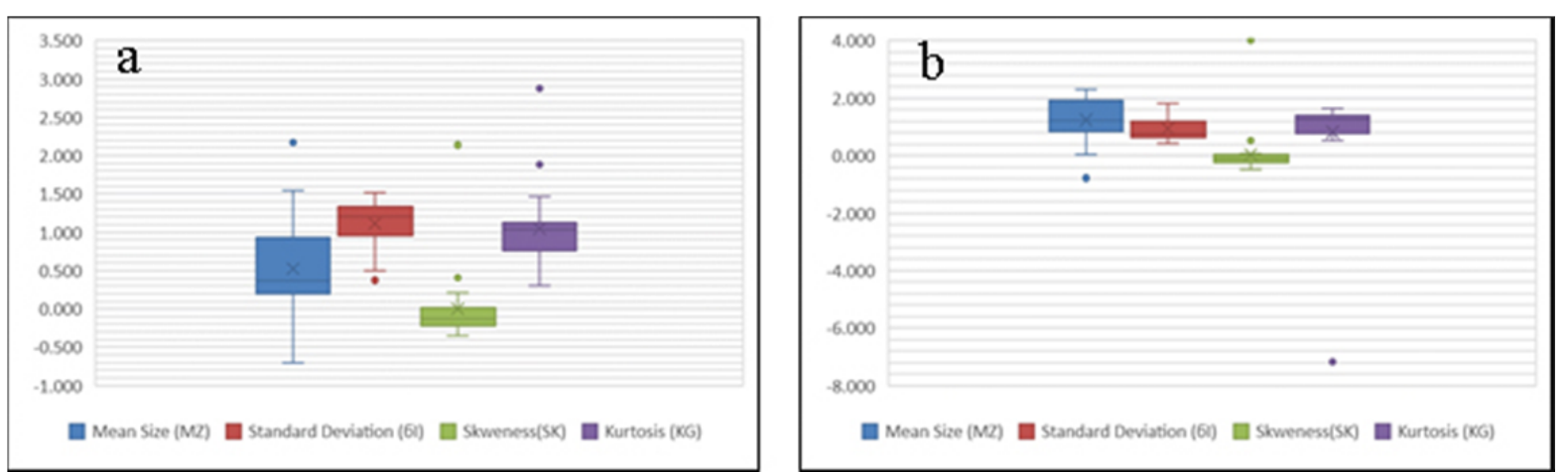

Fig. 4: Boxplot of the grain size parameters for the collected intertidal (a) and beach (b) sediments.

Fig. 5: Comparative histograms of mean size for the studied samples.
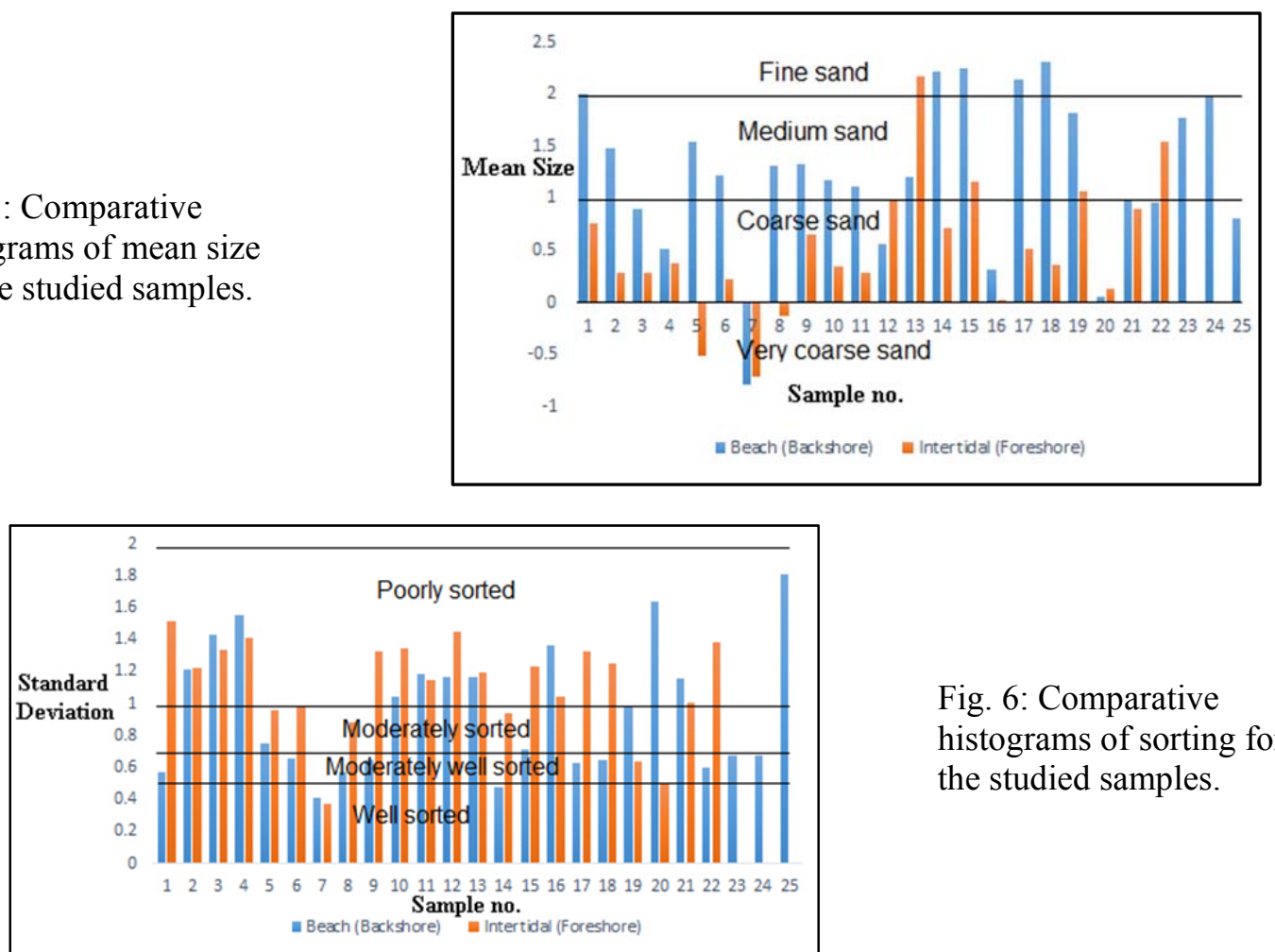

Fig. 6: Comparative histograms of sorting for the studied samples. 
Fig. 7: Comparative histograms of skweness for the studied samples.
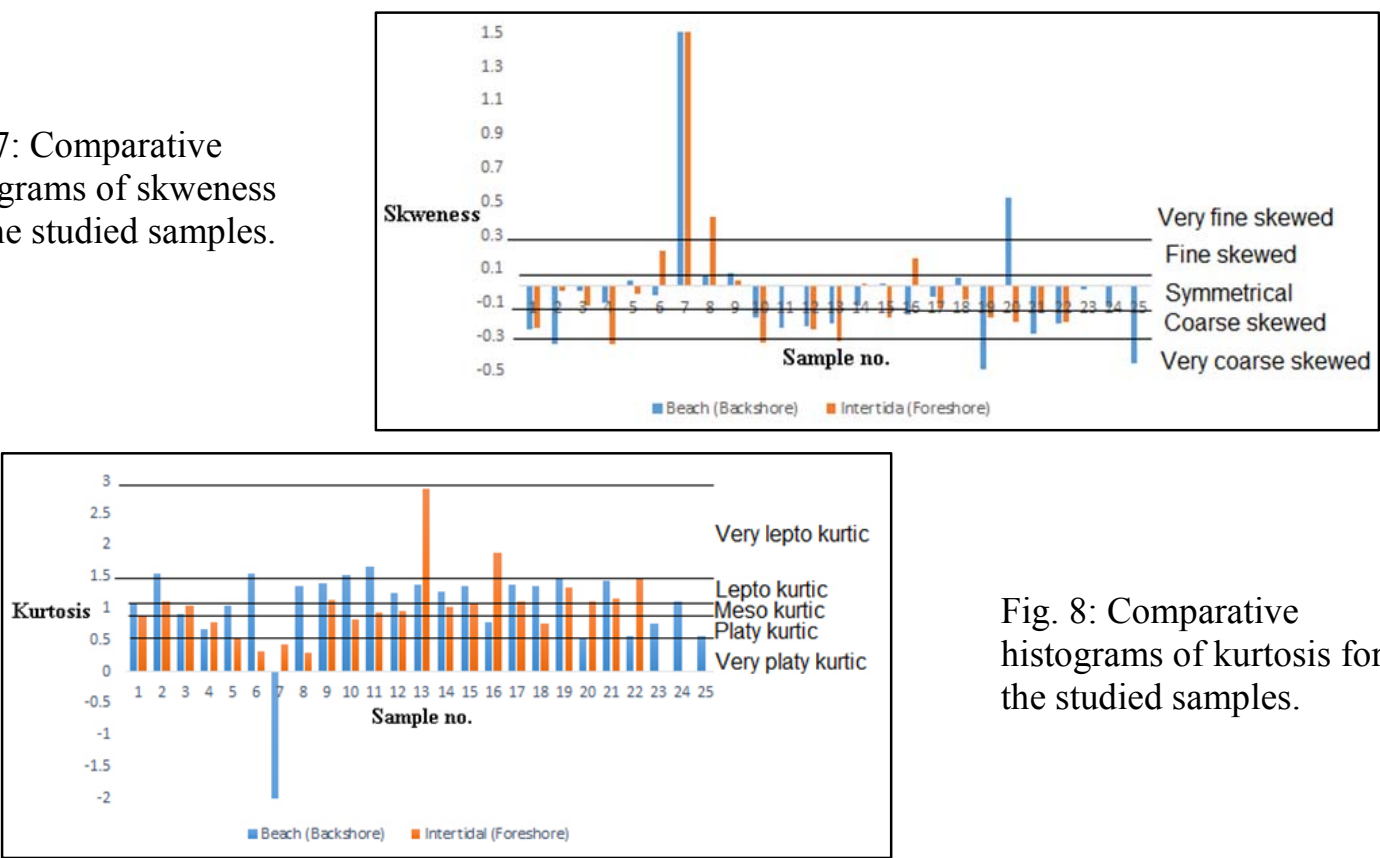

Fig. 8: Comparative histograms of kurtosis for the studied samples.

\section{Results of the heavy mineral analysis}

The results of the calculated (wt \%) of the heavy and light fractions for the studied samples, as well as amount (in wt \%) of the mounted heavy minerals are given in tables $(4 \& 5)$ respectively. The light minerals are quartz, muscovite, potash feldspar and calcite, averaging $75.58 \%, 13.84 \%, 8.20 \%$ and $2.41 \%$ respectively (Table 5). The feldspar minerals are varying from colorless to pale pink colored sub-angular to sub-rounded grains, recommend the presence of albite and potash feldspars respectively. Calcareous and aragonitic shells fragments derived from in-situ breaking-up of foraminiferal and moulluscan shell and coral fragments, are generally coarser than quartz sands, derived from continent, that are common on the intertidal sediments of the studied area.

The different recorded heavy mineral assemblages in the beach sediments are opaque (magnetite and goethite) and non-opaque (pyroxene, barite, biotite, plagioclase, cetrine, sphene, sillimanite, garnet apatite, fluorite, tourmaline, rutile, topaz and olivine) mineral groups. The heavy mineral assemblages were dominated by opaque minerals.

The represented heavy minerals are hence subjected to chemical analyses using Scanning Electron Microscope (SEM). The results are given in Table (6) and figures 9 to 12.

Titano-magnetite is the dominant, magnetite displays as composite grains with deep black color and with metallic to dull luster, their habit ranges from massive, granular and angular to sub-angular (Fig. 9a). Magnetite was represented by homogenous and heterogeneous habit, the latter is usually associated with quartz, and potash feldspar as inclusions.

Pyroxene is more common in the studied samples, pyroxene varieties range from dark green to black to light green or white prismatic crystals to sub-angular grains with vitreous luster (Fig. 9b). Both clinopyroxene and orthopyroxene are detected. High content of Al occurs mainly in orthopyroxenes of high grade Meatiq and El-Fawakhir metamorphic rocks. In most microchemical analyses the content of Ca is no greater than $16.96 \%$ and $\mathrm{Al}$ not greater than $8.50 \%$. In many $\mathrm{Mg}$ - rich orthopyroxene of El-Fawakhir mafic and ultramafic rocks, the bulk of the $\mathrm{Ca}(\mathrm{Mg}, \mathrm{Fe}) \mathrm{Si}_{2} \mathrm{O}_{6}$ initially in solid solution at the temperature of crystallization is exsolved on cooling.

Goethite is opaque commonly angular to sub-rounded grains with submetallic or dull luster, nocleavage and red, reddish black, yellowish and brownish yellow color (Fig. 9c), recorded in all studied samples. Goethite considers the alternation product of many Fe-bearing minerals especially pyrite and so- 
Elshahat, O. R.

called hematite after pyrite (goethite) or pseudo-morphic pyrite. At higher temperatures a very small amount of ferric iron seems to be able to enter 4-corrdinated positions in silicates (Goldschmidt, 1954).

Table 4: Percentage of the investigated intertidal and beach samples (\%).

\begin{tabular}{|c|c|c|c|c|c|}
\hline \multirow[t]{2}{*}{ S. type } & \multirow[t]{2}{*}{ S. No. } & \multicolumn{2}{|c|}{ Very fine sand } & \multicolumn{2}{|c|}{ Fine sand } \\
\hline & & $\%$ of light minerals & $\%$ of heavy minerals & $\%$ of light minerals & $\%$ of heavy minerals \\
\hline \multirow{6}{*}{ 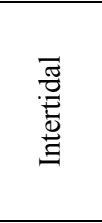 } & 1 & 96.00 & 4.00 & 94.44 & 5.56 \\
\hline & 9 & 42.46 & 57.54 & 56.93 & 43.07 \\
\hline & 12 & 82.43 & 17.57 & 92.51 & 7.49 \\
\hline & 14 & 6.16 & 93.84 & 83.11 & 16.89 \\
\hline & 15 & - & - & 94.40 & 5.60 \\
\hline & 22 & 8.20 & 91.80 & 10.00 & 90.00 \\
\hline \multirow{20}{*}{ 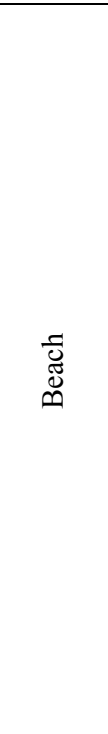 } & 23 & 89.17 & 10.83 & 92.64 & 7.36 \\
\hline & 25 & 83.45 & 16.55 & 95.40 & 4.60 \\
\hline & 26 & 96.47 & 3.53 & 99.04 & 0.96 \\
\hline & 27 & 68.06 & 31.94 & 88.80 & 11.20 \\
\hline & 28 & 75.69 & 24.31 & 90.38 & 9.62 \\
\hline & 29 & 65.22 & 34.78 & 61.96 & 38.04 \\
\hline & 31 & 28.27 & 71.73 & 58.00 & 42.00 \\
\hline & 33 & 2.68 & 97.32 & 45.04 & 54.96 \\
\hline & 34 & 97.87 & 2.13 & 99.00 & 1.00 \\
\hline & 35 & 67.61 & 32.39 & 86.56 & 13.44 \\
\hline & 36 & 54.92 & 45.08 & 91.46 & 8.54 \\
\hline & 37 & 84.88 & 15.12 & 98.00 & 2.00 \\
\hline & 38 & 71.30 & 28.70 & 87.94 & 12.06 \\
\hline & 39 & 70.00 & 30.00 & 86.83 & 13.17 \\
\hline & 40 & - & - & 84.14 & 15.86 \\
\hline & 42 & 46.64 & 53.36 & 60.07 & 39.93 \\
\hline & 43 & 81.45 & 18.55 & 99.66 & 0.34 \\
\hline & 44 & 87.62 & 12.38 & 95.20 & 4.80 \\
\hline & 45 & 90.20 & 9.80 & - & - \\
\hline & 47 & 53.99 & 46.01 & 58.61 & 41.39 \\
\hline
\end{tabular}

Table 5: A mount (in wt \%) of the mounted heavy and light minerals in the investigated samples.

\begin{tabular}{|c|c|c|c|c|c|c|c|c|c|c|c|c|c|c|c|c|c|c|}
\hline & \multicolumn{4}{|c|}{ Light minerals } & \multicolumn{14}{|c|}{ Heavy minerals } \\
\hline & $\mathrm{Qz}$ & $\mathrm{Pf}$ & $\mathrm{Mu}$ & $\mathrm{Ca}$ & Py & Go & $\mathrm{Ma}$ & Bio & $\mathrm{Pl}$ & $\mathrm{Ba}$ & $\mathrm{O}$ & $\mathrm{Tz}$ & $\mathrm{Ru}$ & To & Ap & $\mathrm{Ga}$ & $\mathrm{S}$ & $\mathrm{Si}$ \\
\hline Min. & 50 & 1.2 & 2 & 0 & 2.5 & 8 & 13 & 1.5 & 2 & 2 & 1.5 & 0 & 0.1 & 0 & 0 & 0 & 0 & 0 \\
\hline Max. & 92.5 & 19 & 31 & 6 & 35 & 30 & 65.5 & 13 & 5 & 25 & 9 & 0.6 & 4 & 2 & 4 & 2 & 0.6 & 2.5 \\
\hline Avg. & 75.5 & 8.2 & 13.8 & 2.4 & 14.9 & 13.1 & 42 & 5.8 & 3.4 & 9.7 & 5.1 & 0.2 & 1.5 & 0.6 & 2 & 0.6 & 0.3 & 0.5 \\
\hline
\end{tabular}

Qz: quartz, Pf: potash feldspar, Mu: muscovite, Ca: calcite, Py: pyroxene, Go: goethite, Ma: magnetite, Bio: biotite, Pl: plagioclase, Ba: barite, O: olivine, Tz: topaz, C: cetrine, Ru: rutile, To: tourmaline, AP: apatite, Ga: granite, $\mathrm{S}$ : sphene, Si: sillimanite.

Table 6: Chemical composition of some selected heavy minerals.

\begin{tabular}{|c|c|c|c|c|c|c|c|c|c|c|c|c|c|}
\hline & Magnetite & Ilmenite & $\begin{array}{l}\text { Ortho- } \\
\text { pyroxene }\end{array}$ & $\begin{array}{l}\text { Clino- } \\
\text { pyroxene }\end{array}$ & Goethite & Biotite & Olivine & Albite & Apatite & Sillimanite & Tourmaline & Garnet & Sphene \\
\hline $\mathrm{Fe}$ & 73.89 & 48.26 & 19.53 & 22.50 & 86.13 & 7.49 & 6.71 & 1.46 & & 2.33 & 2.16 & 35.08 & 4.41 \\
\hline $\mathrm{Si}$ & 3.27 & 5.14 & 19.92 & 42.42 & 9.13 & 34.08 & 55.5 & 67.24 & 1.42 & 69.78 & 49.78 & 30.39 & 19.22 \\
\hline $\mathrm{Al}$ & 1.94 & 1.17 & 8.50 & 3.61 & 3.65 & 9.96 & & 16.89 & & 17.36 & 47.34 & 16.91 & 2.16 \\
\hline $\mathrm{Ca}$ & 1.43 & 3.26 & 9.24 & 16.96 & 1.09 & 8.89 & & 2.77 & 70.24 & 0.81 & & 10.64 & 32.78 \\
\hline $\mathrm{Ti}$ & & 37.79 & & 0.87 & & 4.24 & & & & & & 0.40 & 38.78 \\
\hline $\mathrm{Mg}$ & 3.83 & 1.70 & 18.53 & 13.64 & & 14.58 & 37.7 & 1.84 & & & 1.41 & 2.23 & 2.65 \\
\hline $\mathrm{Mn}$ & & 2.69 & & & & & & & & & & 4.34 & \\
\hline $\mathrm{Cl}$ & & & 14.04 & & & & & & & & & & \\
\hline $\mathrm{K}$ & 0.49 & & 0.55 & & & 0.76 & & & & & & & \\
\hline $\mathrm{S}$ & & & 2.05 & & & & & & & & & & \\
\hline $\mathrm{O}$ & 15.16 & & & & & & & & & & & & \\
\hline $\mathrm{Na}$ & & & 7.65 & & & & & 9.79 & & 9.72 & & & \\
\hline $\mathrm{P}$ & & & & & & & & & 28.33 & & & & \\
\hline
\end{tabular}


Textural - heavy minerals characterization of foreshore - backshore

Fig. 9: Photomicrograph, BSE and EDX semiquantitative chemical analysis (Wt.\%) of a) magnetite and ilmenite, b) clinopyroxene and orthopyroxene and c) goethite minerals.

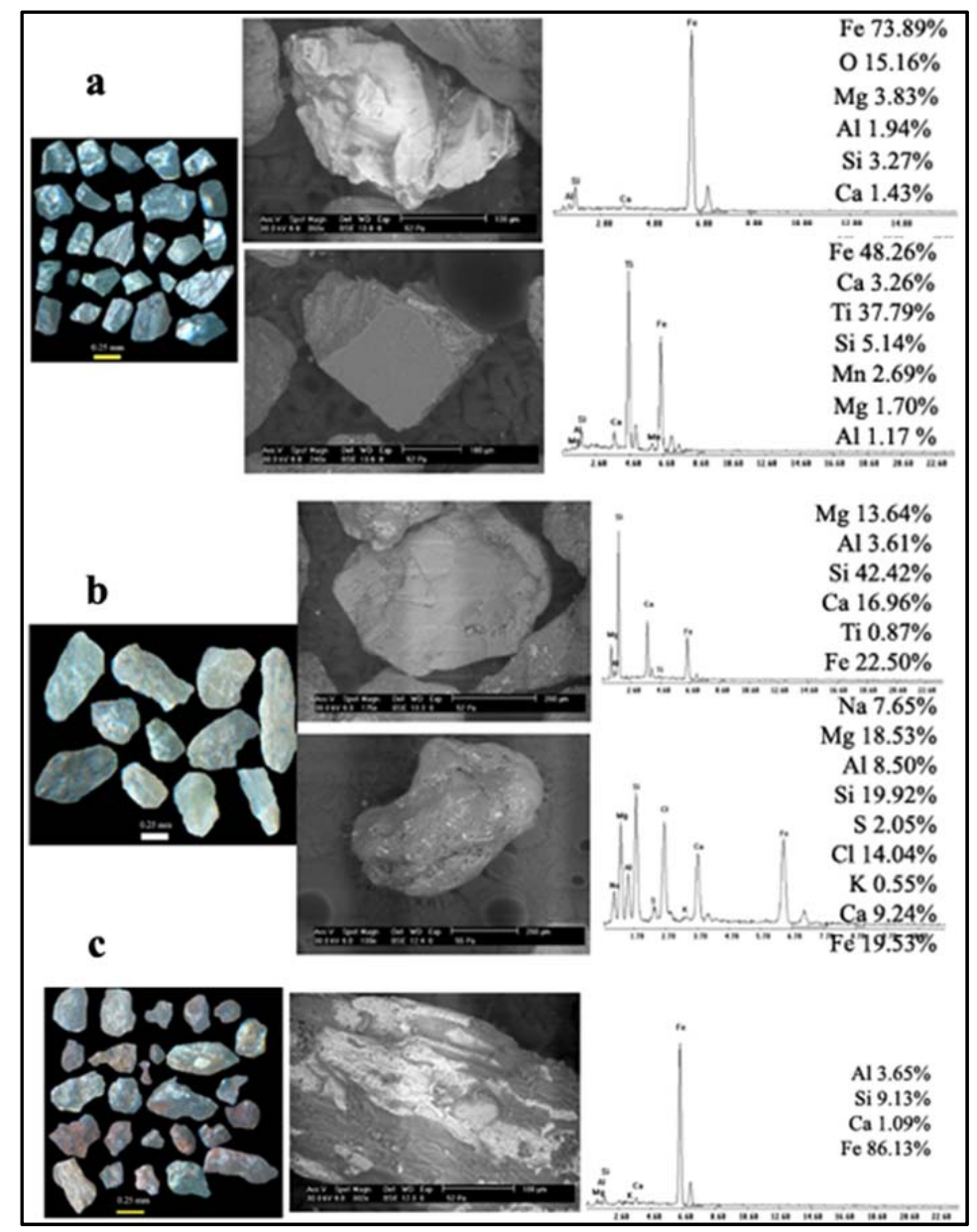

Biotite occurs usually as brown to yellowish brown, grey flakes and subhedral crystals (Fig. 10a). The composition of most biotites fall within the field outlined by four end-members, phlogopite, annite, eastonite and siderophyllite. Thus, in the studied biotite as compared with phlogopite, magnesium is replaced by ferrous iron and also trivalent ions $\left(\mathrm{Fe}^{+3}, \mathrm{Al}\right)$, and aluminum replaces silicon in tetrahedral sites (Deer et al., 2001). Also, there are other substitutions for $\mathrm{K}$ : $\mathrm{Na}$ and $\mathrm{Ca}$ occurred in the studied biotites. Calcium is usually present in higher concentration than the others in the present biotites.

Sillimanite found as yellowish to dark yellowish-brown irregular, angular (somewhat platy) grains (Fig. 10b). The sillimanite composition is fairly constant and relatively close to $\mathrm{Al}_{2} \mathrm{SiO}_{5}$. The commonest ion replacing $\mathrm{Al}$ in the structure of sillimanite is $\mathrm{Fe}^{3+}$. There are small amounts of other elements sometimes reported probably represent as impurities. This due to the detected sodium in the microchemical analysis of the studied sillimanite.

Olivine occurs as sub-angular and sub-rounded grains with Pale olive green to yellow-green and transparent to translucent with a glassy luster (Fig. 10c). Olivines vary in composition from forsterite $\left(\mathrm{Mg}_{2}\right.$ $\left.\mathrm{SiO}_{4}\right)$, to fayalite $\left(\mathrm{Fe}_{2} \mathrm{SiO}_{4}\right)$, there being complete diadochy between $\mathrm{Mg}$ and $\mathrm{Fe}^{2+}$ in the structure (Goldschmidt, 1954). The detected olivine by microchemical analysis is recorded as forsterite.

Apatite recorded as small prismatic well crystalline of good vitreous luster with indication of some inclusions inside the grains (Fig. 10d). The little amount of silicon that recorded in microchemical analysis of apatite resulted from replacement of calcium by silicon.Albite found as white to gray yellowish, crystals with vitreous (glass-like) to porcelain-like luster (Fig. 10e).

Tourmaline occurs as colorless, grey and greenish color, long slender to thick prismatic and columnar crystals with termination at one end (Fig. 11a). In the formula $\mathrm{Na}_{3} \mathrm{Al}_{6} \mathrm{~B}_{3} \mathrm{Si}_{6} \mathrm{O}_{27}(\mathrm{OH})_{4}$. Na may be 
Elshahat, O. R.

partially replaced by $\mathrm{K}$ or by $\mathrm{Ca}$. In the studied tourmaline crystals $\mathrm{R}$ can be predominantly $\mathrm{Fe}^{+2}(2.16 \%)$ as in schorl and $\mathrm{Mg}(1.41 \%)$ as in dravite.

Garnet is represented by dark brown to pale pink sub rounded to rounded crystals with characteristic vitreous luster (Fig. 11b) Substitutions which can tack place in the garnet structure include the possible replacement of a small proportion of the $\mathrm{Si}$ atoms by $\mathrm{P}$ or perhaps by $\mathrm{Ti}$, also replace $\mathrm{Al}$ and $\mathrm{Mg}$ (Derr et al., 2001). The substitution between $\mathrm{Al}$ and $\mathrm{Mg}$-Fe take place in the studied garnet-bearing schists and gneisses at W. El-Jimal and Hafafite areas, to give almandine $\left(\mathrm{Fe}_{3} \mathrm{Al}_{2} \mathrm{Si}_{3} \mathrm{O}_{12}\right)$ and pyrope $\left(\mathrm{Mg}_{3} \mathrm{Al}_{2} \mathrm{Si}_{3} \mathrm{O}_{12}\right)$ types.

Sphene has color varies from yellowish to brownish yellow and has regular wedge shape with vitreous luster (Fig. 11c).

The barite is represented by yellow, grey, brown angular to sub-rounded grains (Fig. 12a). Rutile found as angular and slightly rounded brown-red grains (Fig. 12b). Topaz color varies from pink, light purple, it also ranges from transparent to translucent (Fig. 12c).

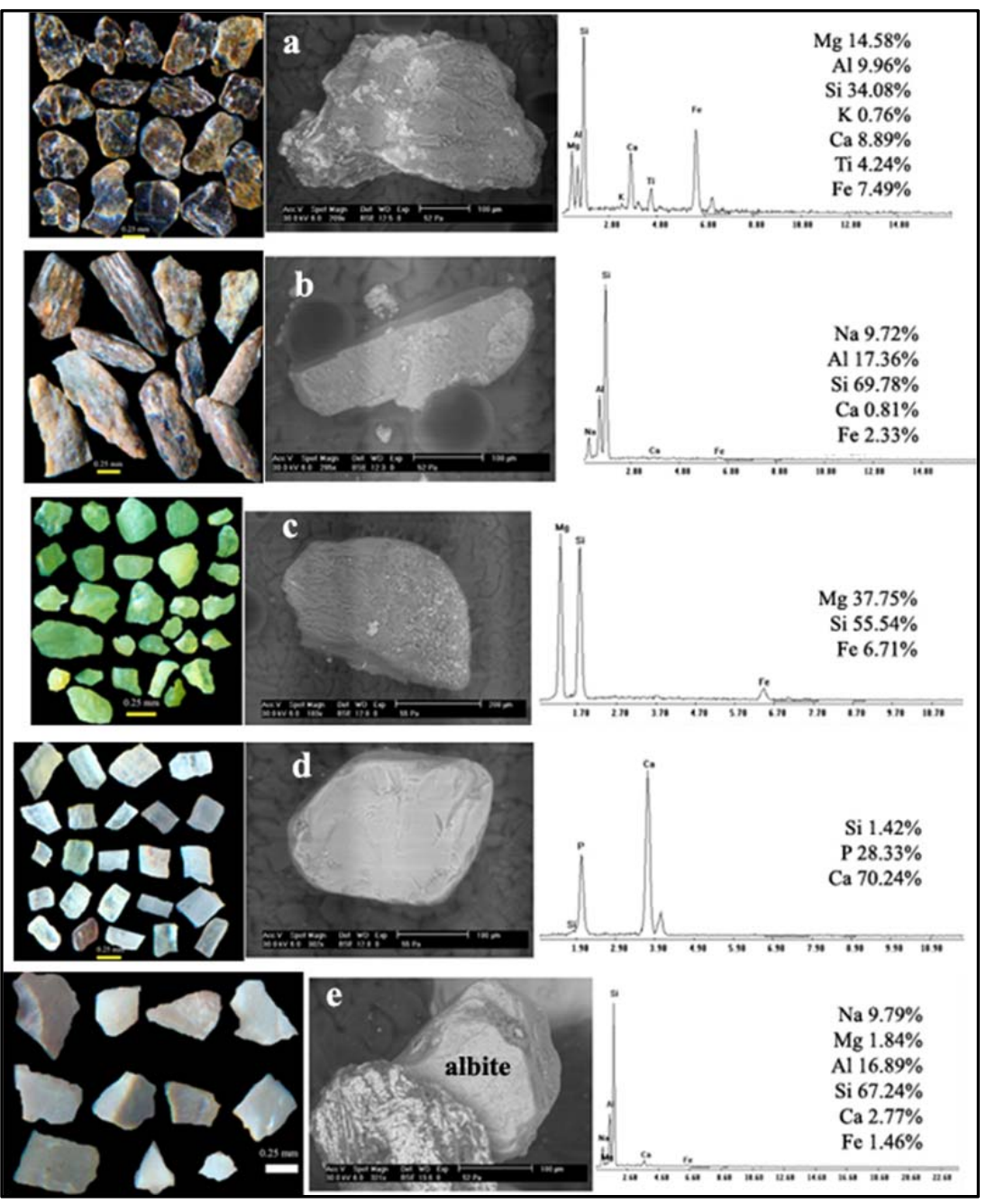

Fig. 10: Photomicrograph, BSE and EDX semiquantitative chemical analysis (Wt.\%) of a) biotite, b) sillimanite, c) olivine, d) apatite and e) albite minerals. 
Textural - heavy minerals characterization of foreshore - backshore

Fig. 11: Photomicrograph, BSE and EDX semiquantitative chemical analysis (Wt.\%) of a) tourmaline, b) garnet and c) sphene minerals.
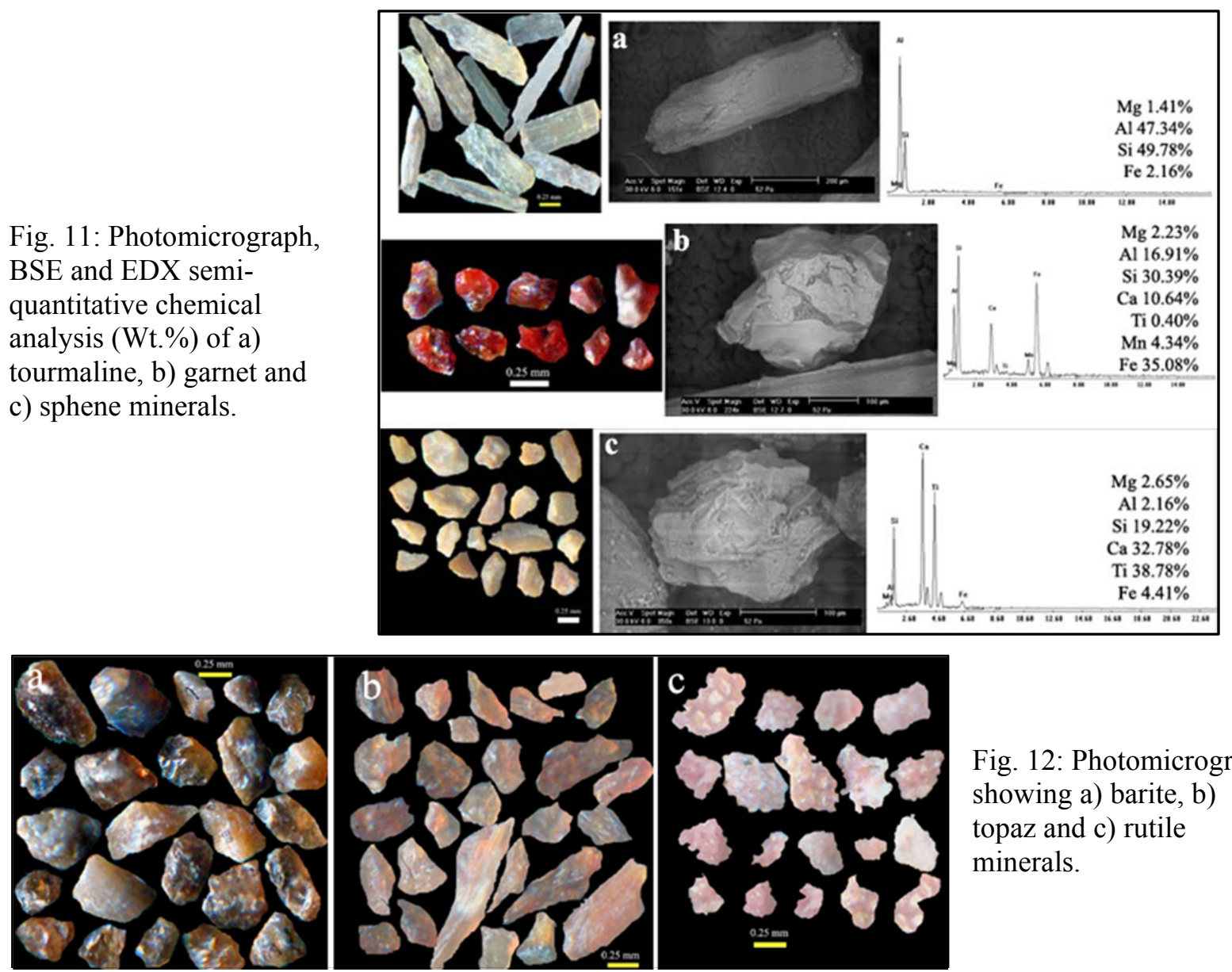

Fig. 12: Photomicrograph showing a) barite, b) topaz and c) rutile minerals.

\section{Source rocks of the detected heavy minerals}

In fact, the bulk of the stream sediments along the Marsa Alam and the entrance of Wadi Jimal have been mainly derived from the basement rocks which comprise many types of plutonic rocks and metamorphic rocks assemblages encountered in Wadi Alam, Wadi Samadai, Wadi Ghadir and Wadi ElJimal.

The presence of pyroxene (clino-ortho-), hornblende, olivine, magnetite, goethite and ilmenite point essentially to basic igneous and mafic-ultramafic rocks. The basic igneous rocks represented by gabbroic rocks, dolorite and basaltic rocks.

Muscovite, biotite, albite plagioclase, potash feldspar, rutile, titanite (sphene), apatite point to acidic igneous rocks. Tourmaline comes from pegmatites and pegmatitic granites. The acidic igneous rocks in the studied district represented by alkali feldspar granites, granodiorites, tonalite, quartz diorite, monzogranite, syenogranites and rhyolite. The metamorphic rocks in Sakit, Nuqrus and Hafafit mountains are the main sources of sillimanite.

\section{CONCLUSIONS}

From the grain-size analysis and heavy minerals separation the important conclusions drawn are as follows: the highly variation in grain size indicates the variation in the kinetic energy at the time of deposition and suggests strong to moderate energy conditions of deposition. The observed sorting variation attributes to the difference in water turbulence and variability in the velocity of depositing current and likely due to continuous addition of finer/coarser materials in varying proportions. 
Elshahat, O. R.

The variation in the skewness values in agreement with the change in the energy conditions in the study area. The variation of kurtosis from very platykurtic to very leptokurtic indicates multiple environment i.e. one derived from riverine/aeolian environment and the other primarily derived from marine environment. A Bivariate plot shows that most samples plotting in the beach sand zone. The studied sediments were deposited predominantly by beach with influence of fluvial process under shallow agitating environment and carried by turbidity action.

The different recorded heavy mineral assemblages in the studied sediments can be classified into opaques and non-opaques groups. The opaque minerals are goethite and magnetite, the non-opaque minerals are pyroxene, barite, biotite, plagioclase, cetrine, sphene, sillimanite, garnet apatite, fluorite, tourmaline, rutile, topaz and olivine.

About $50 \%$ of the studied beach samples contain $97.8-31.9 \%$ heavy minerals. The ore minerals of economic importance are magnetite, goethite and barite $(\sim 65 \%$ in average $)$. The other mineral constituents chiefly pyroxene, biotite, olivine, rutile and apatite are industrial minerals. That can be recommended the study area for detailed study as economic black sands bearing ore and industrial minerals.

The wadies are the receivers for the disintegrated materials from the surrounding mountain rocks contributed by the rainwater and weathering conditions.

\section{REFERENCES}

Abdulkareem, R. Akintoye, A. E. Oguwuike, I. D. Imhansoeleva, T. M. Philips, I. M. Ruth, F. B. Olubukola, S. O. Rasheed, J. O. and Banji, A. O. (2011): Sedimentological variation in beach sediments of the barrier bar lagoon coastal system, South -western Nigeria. Nature and Sci., 9, 19-26.

Ahmed, W. M. (2005): Geochemistry and sedimentology of core sediments and the influence of human activities; Qusier, Safaga and Hurghada Harbors, Red Sea Coast, Egypt. Egyptian J. of Aquatic Res., 31, (1), 92-103.

Amireh, B. S. (2014): Grain size analysis of the Lower Cambrian-Lower Cretaceous clastic sequence of Jordan, Sedimentological and paleo-hydrodynamical implications. J. Asian Earth Sci., 97, 67-88.

Arafat, A.A., Salama, M.H., El-Sayed, S.A., and Elfeel, A.A. (2017): Distribution of natural radionuclides and assessment of the associated hazards in the environment of Marsa Alam-Shalateen area, Red Sea coast, Egypt. J. of Radiation Research and Applied Sciences, 10, 219-232.

Avramidis P. Samiotis A. Kalimani E. Papoulis D. Lampropoulou P. and Bekiari V. (2012): Sediment characteristics and water physicochemical parameters of the Lysimachia Lake, Western Greece. Environ Earth Sci., 70 (1), 383-392.

Blott, S. J. and Pye, K. (2001): GRADISTAT: a grain size distribution and statistics package for the analysis of unconsolidated sediments. Earth Surface Processes and Landforms, 26, 1237-1248.

Deer W. A. Howie R. A. and Zussman J. (2001): An introduction to the rock-forming minerals. $2^{\text {nd }} E d$., Longman, London, 972p.

El Mamoney, M. H. and Khater E. M. (2004): The environmental characterization and radio-ecological impacts of non-nuclear industries on the Red Sea coast. J. of Environ Radioactivity, 73, 151-168.

EL-Mamoney, M. H. and Rifaat, A. E. (2001): Discrimination of Sources of Barium in Beach Sediments, Marsa Alam-Shuqeir, Red Sea Coast, Egypt. J. King Abdulaziz Univ., 12 (1), 149-160.

Folk, R. L. (1954): The distinction between grain size and mineral composition in sedimentary-rock nomenclature. J. of Geology, 62, 344-359.

Folk, R. L. and Ward, W. C. (1957): Brazos River Bar: A study in the significance of grain size parameters. J. Sed. Pet., 27, 3-27.

Friedman G. M. (1962): On sorting, sorting coefficients and the log normality of the grain size distribution of sandstones. J. Geol., 70(6), 737-755.

Friedman G. M. and Sanders J. E. (1978): Principles of sedimentology, Wiley, New York, 792 p.

Fritz, H. Wallbrecher, E. Khudeir, A. A. Abu el Ela, F. and Dallmeyer, D. R. (1996): Formation of Neoproterozoic metamorphic core complexes during oblique convergence (Eastern Desert, Egypt). J. Afri. Earth Sci., 23, 311-329. 
Textural - heavy minerals characterization of foreshore - backshore

Goldschmidt, V. M. (1954): Geochemistry: Clarendon Press, Oxford, 730 p.

Greene, D. (1984): Structural geology of the Quseir area, Red Sea coast, Egypt. Contribution Number 52, Department of Geology and Geography, University of Massachusetts, Amherst, Massachusetts.

Greiling, R. O. Abdeen, M. M. Dardir, A. A. El Akhal, H. El Ramly, M. F. Kamal El Din, G. M. Osman, A. F. Rashwan, A. A. Rice, A. H. and Sadek, M. F. (1994): A structural synthesis of the Proterozoic Arabian - Nubian Shield in Egypt. Geol. Rundsch., 83, 484-501.

Ingram, R. L. (1971): Sieve analysis". In: R.E. Carver (Ed.), Procedures in Sedimentary Petrology. Wilson Inter. science, 49-68

Inman D. L. and Chamberlain F. K. (1955): Particle size distribution in near-shore sediments, [in:] Finding ancient shorelines, J. L. Hough \& H.W. Mearad (eds.), Soc. Econ. Paleont. Miner. Spec. Publ. $3,06-129$.

Kröner, A. Krüger, J. Rashwan, A. A. (1994): Age and tectonic setting of granitoid gneisses in the Eastern Desert of Egypt and south-west Sinai. Geol. Rundschau, 83, 502-513.

Neumayr, P. Hoinkes, G. Puhl, J. Mogessie, A. and Khudier, A. A. (1998): The Meatiq dome (Eastern Desert, Egypt) a Precambrian metamorphic core complex: Petrological and geological evidence. J. of Metamorphic Geology, 16, 259-279.

Rajganapathi, V. C. Jitheshkumar, N. Sundararajan, M. Bhat, K. H. and Velusamy, S. (2013): Grain size analysis and characterization of sedimentary environment along Thiruchendar coast, Thamilnadu, India, Arabic J. of Geoscience 6, 4717-4728.

Ramadan, F. S. and Zaid S. M. (2016): Provenance of recent sediments, along the Red Sea coast, Egypt. International J. of Academic Research Part A; 5(2), pp. 38-49.

Ries, A. C. Shackleton, R. M. Graham, R.H. and Fitches, W. R. (1983): Pan-African structures, ophiolites and melange in the Eastern Desert of Egypt: a traverse at $26^{\circ} \mathrm{N}$ : Geol. Soc. London J., 140, 75-95.

Said, R. (1990): The Geology of Egypt: 734 pp. Rotterdam (Balkema).

Singarasubramanian, S. R. Mukesh M. V. Manoharan K. Murugan S. Bakkiaraj D. and John Peter A. (2006): Sediment characteristics of the M-9 tsunami event between Rameswaram and Thoothukudi, Gulf of Mannar, Southeast Coast of India. Sci Tsunami Hazards, 25,160-172.

Valentine, M. (1985): Structure and Tectonics of the Southern Gebel Duwi area, astern Desert of Egypt. Contribution No. 53, Department of Geology and Geography, University of Massachusetts, Amherst, Massachusetts.

Venkatramanan, S. Ramkumar, T. Anithamari, I. and Ramesh, G. (2011): Variation in texture of beach sediments in the vicinity of the Thirumalairajanar river mouth of India, International J. of Sedi. Research, 26, 460-470.

Watson, E. B. Pasternack, G. B. Gray, A. B. Goni, M. and Woolfolk, A. M. (2013): Particle size characterization of historic sediment deposition from a closed estuarine lagoon, Central California, Estuarine. Coastal and Shelf Science, 126, 23-33.

Zaid, S. M. (2015): Geochemistry of sandstones from the Pliocene Gabir Formation, north Marsa Alam, Red Sea, Egypt: Implication for provenance, weathering and tectonic setting. J. of African Earth Sciences, 102, 1-17. 
Elshahat, O. R.

الخصائص النسيجية والمعادن الثقيلة للرواسب الأمامية والخلفية ، مرسى علم - وادى الجمال المنطقة الساحلية للبحر الأحمر ، مصر اسامه رمزى الشحات

\section{قسم الجيولوجيا - كلية العلوم - جامعة الأزهر}

\section{الخلاصة}

تهدف الدراسة إلى تفسير المعاملات النسيجية ومعرفة المحتوى المعدنى لرواسب المد والثناطئ على طول المنطقة الواقعة بين مرسى علم ومدخل وادي الجمال. نم استخدام المعطيات الناتجة عن التحليل الحجم للحبيبات لحساب المعاملات النسيجية مثل الحجم السائد، الانحراف المعياري، التدرج فى حجم الحبيبات و درجة التفرطح تبين من الدراسة ان الرواسب الددية تتكون

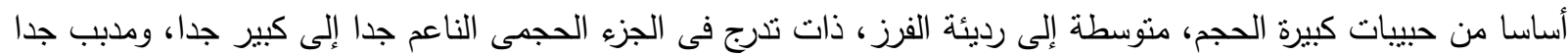

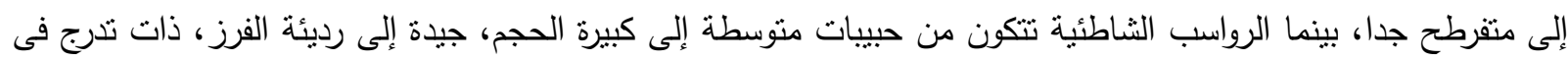
الجزء الحجمى الكبير إلى منمانلة، ومدبب جدا إلى متفرطح جدا.

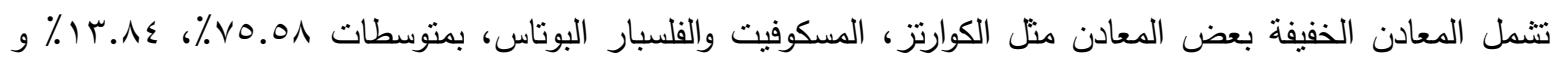

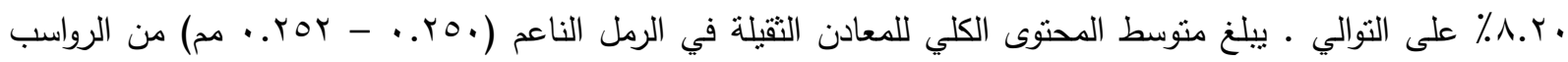

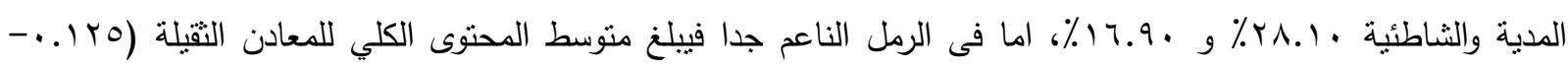

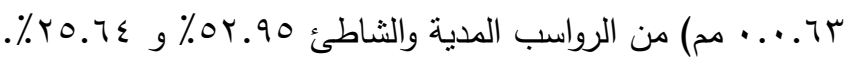

ويمكن تصنيف تجمعات المعادن الثقيلة المسجلة في الرواسب المدية و الثاطئية إلى معنمة منل الجوتايت، المجنيتيت و

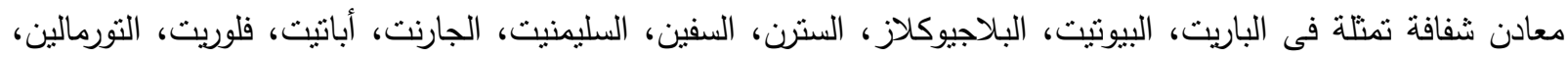

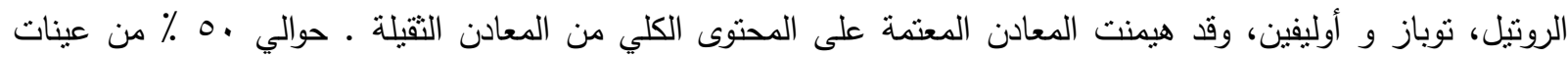

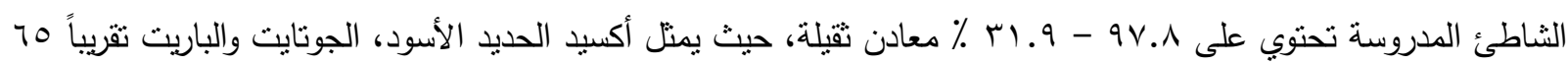
\% في المتوسط والمكونات المعدنية الأخرى بشكل رئيس البيروكسين، البيوتايت، الاولفين، الروتيل والأباتيت هي معادئ

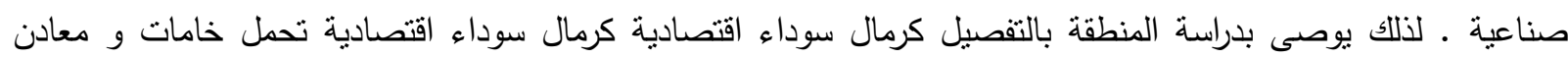

تعتبر صخور الجابرو والدولوريت والبازلت والجرانيتات والجرانوديوريت القلوية والتوناليت والمنزوجرانيت والسيانوجرانيت والصخور المتحولة الموجوده في وادي علم ووادي سماداي وادي غدير ووادي الجمال المصدر الرئيسي للمعادن التقيلة المدروسة . 